Research article

\title{
BRIX REFRACTOMETRY OF COLOSTRUM FROM PRIMIPAROUS DAIRY COWS AND NEW-BORN CALF BLOOD SERUM IN THE EVALUATION OF FAILURE OF PASSIVE TRANSFER
}

\author{
STOJIĆ Milica ${ }^{1}$, FRATRIĆ Natalija ${ }^{1 *}$, KOVAČIĆ Marijana ${ }^{2}$, ILIĆ Vesna ${ }^{2}$, \\ GVOZDIĆ Dragan ${ }^{3}$ SAVIĆ Olivera ${ }^{4}$, ĐOKOVIĆ Radojica ${ }^{5}$, VALČIĆ Olivera ${ }^{1}$
}

\begin{abstract}
${ }^{1}$ Department of Physiology and Biochemistry, Faculty of Veterinary Medicine, University of Belgrade, Bulevar oslobođenja 18, Belgrade, Serbia; ${ }^{2}$ Institute for Medical Research, University of Belgrade, Dr Subotića 4, Belgrade, Serbia; ${ }^{3}$ Department of Pathophysiology, Faculty of Veterinary Medicine, University of Belgrade, Bulevar oslobođenja 18, Belgrade, Serbia; ${ }^{4}$ Institute for Blood Transfusion of Serbia, Svetog Save 39, Belgrade, Serbia; ${ }^{5}$ Faculty of Agronomy, University of Kragujevac, Cara Dušana 34, Čačak, Serbia
\end{abstract}

(Received 29 March, Accepted 07 June 2017)

Failure of passive transfer (FPT) of immunoglobulins ( $\operatorname{IgG}$ ) is associated with increased morbidity and mortality of calves. In this study we evaluated the digital Brix refractometer usefulness for the assessment of FPT. A number of 16 colostrum samples from the first milking (2-3h post-partum) of Holstein-Friesian dairy heifers and 29 blood sera of 3-6 days old calves were analyzed with a digital Brix refractometer. Total proteins were determined by the biuret reaction. Colostral $\operatorname{IgG}$ were determined by radial immunodiffusion (RID), and colostral whey and blood serum $\gamma$ globulin (composed almost entirely of $\operatorname{IgG}$ ) were determined by agarose protein gel electrophoresis (APE) and densitometry. Colostral \% Brix score was $25.5 \pm 3.4 \%$. Concentrations of colostrum $\mathrm{IgG}$ and colostral whey $\gamma$ globulin were $130 \pm 33 \mathrm{~g} / \mathrm{L}$ and $100 \pm 24 \mathrm{~g} / \mathrm{L}$ respectively. The concentration of total proteins in colostral whey was $134 \pm 30 \mathrm{~g} / \mathrm{L}$. The correlations between Brix values and the concentrations of $\operatorname{IgG}$ determined with RID and the concentrations of $\gamma$ globulin determined with APE were positive and highly significant $(\mathrm{P}<0.001$ and $\mathrm{P}<0.01)$. The concentration of serum proteins of new-born calves was $57.75 \pm 11.8 \mathrm{~g} / \mathrm{L}$, the concentration of $\gamma$ globulin was $14.4 \pm 7.8 \mathrm{~g} / \mathrm{L}$, and the Brix score was $8.6 \pm 1.0 \%$. FPT (serum $\gamma$ globulin $<10 \mathrm{~g} / \mathrm{L}$ ) was detected in $34.5 \%(10 / 29)$ calves. Brix score correlated with the concentration of blood serum $\gamma$ globulins in all examined calves. The results have confirmed that digital Brix refractometry allows the producers to use this technique in order to estimate colostral and calf serum IgG, thereby monitoring both colostrum quality and success of passive transfer.

Key words: agarose gel protein electrophoresis, brix refractometer, colostrum $\operatorname{IgG}$, failure of passive transfer, new-born calf sera IgG, radial immunodiffusion.

\footnotetext{
*Corresponding author: e-mail: nataly@vet.bg.ac.rs
} 


\section{INTRODUCTION}

Colostrum is an important source of immunity and nutrition for the neonate. It contains immunoglobulins and functional proteins, lipids, carbohydrates, growth factors, minerals and vitamins. Adequate intake of high quality colostrum immediately after birth is the most important factor which determines calf health, survival and future production [1]

Newborn calves are agammaglobulinemic, or might have IgG in traces [2,3]. They derive passive immunity by absorbing immunoglobulins and leukocytes from the colostrum [2,4-6]. Protection from infectious diseases of newborn calves is completely dependent on the success of passive transfer of maternal IgG via the colostrum [2]. Because of that, failure of passive transfer (FPT) of colostral immunoglobulins, composed mainly of IgG [2], is associated with increased morbidity and mortality [211]. FPT of immunoglobulins is defined as a circulating $\operatorname{IgG}$ concentration less than $10 \mathrm{~g} / \mathrm{L}$ in newborn calves between 24 and 48 hours of age $[12,13]$.

A variety of methods is available to evaluate colostrum quality. Immunochemical techniques (immune-nephelometry, radial immunodiffusion; RID, turbidimetric immunoassay; TIA, enzyme-linked immunosorbent assay; ELISA) are considered as the most accurate methods for analysis of $\operatorname{IgG}$ in the colostrum and milk $[14,15]$. Among them the most accurate method for analysis of $\mathrm{IgG}$ in the colostrum is radial immunodiffusion (RID) assay that directly measures the $\operatorname{IgG}$ concentration and represents the gold standard for the determination of $\mathrm{IgG}$ concentration in the bovine colostrum or serum. The RID assay is an expensive laboratory procedure, demands special equipment and educated technicians. Besides, it is time consuming (requires 18 to $72 \mathrm{~h}$ to determine the results), and as such, it is not suitable for on-farm use $[16,17]$.

Alternative to theimmunochemicalassay, electrophoretic techniques (gelelectrophoresis, capillary electrophoresis) and high-performance chromatographic techniques have been used for the determination of bovine colostral whey proteins [14]. The agarose gel serum protein electrophoresis (APE) is the mostly used electrophoretic technique for diagnostics in both human and veterinary medicine allowing thus the identification and quantification of protein fractions in different body fluids [18]. Electrophoretic determination of $\operatorname{IgG}$ concentration is reliable, more rapid and less expensive then RID, but it also demands special equipment, technical knowledge, and it is also time consuming and not suitable for on-farm use.

Physical techniques, including colostrometry and refractometry are also used for the assessment of colostrum quality [1]. The most common methods for assessing colostrum quality are colostrometry (hydrometry) and visual inspection. The colostrometer was introduced as a practical field tool for measuring $\operatorname{IgG}$ concentration in bovine colostrum based on the linear relationship between colostral specific gravity and $\operatorname{IgG}$ concentration [19]. Although colostrometry allows the producers a fast assessment of colostrum quality, it is often inaccurate [20] because it depends on the colostrum temperature [21,22], cow breed, month of calving and parity [20]. 
Consequently an alternative, reliable/accurate, rapid, inexpensive and easy to use method for on-farm monitoring of colostrum management as a predictor of calf health is needed. Refractometers, digital or optical, are used to measure total protein in the colostrum and calf serum [1,23-25]. The digital Brix refractometer measures the index of refraction. Proteins in body fluids refract light and refractometry is an indirect measure of the concentration of total proteins [26]. The major protein fraction in the colostrum is $\operatorname{IgG}$, thus, measurement of total protein in the colostrum may provide a value that is highly correlated with $\operatorname{IgG}$ concentration $[15,27]$. Refractometry using a Brix refractometer has advantages over other methods for estimating the concentration of colostral IgG. It is inexpensive, readily available, less fragile and not sensitive to the temperature of the colostrum at the time of analysis, season of the year and other factors [24].

Brix refractometer is not used in our country. This is the first study where we evaluated its usefulness for the measurement of colostrum IgG concentration on our farms. We determined the correlation between the refractometry values obtained by Brix and the IgG concentration determined with RID (gold standard) and $\gamma$ globulins determined with APE. Besides, we analyzed if Brix refractometry of colostrum and new-born calf serum can be used for the assessment of the success of passive transfer of maternal immunoglobulins.

\section{MATERIAL AND METHODS}

\section{Animals}

Holstein-Friesian pregnant heifers $(n=16)$ and 3-6 days old Holstein-Friesian calves $(n=29)$ were from a farm owned by PKB Corporation (Padinska Skela, Belgrade, Serbia). The use of animals was approved by the Ethical Committee of the Faculty of Veterinary Medicine, University of Belgrade in accordance with the National Regulation on Animal Welfare. All heifers and calves were in good general health condition without any obvious clinical signs of disease. Gestation length of the dams of the calves was in the range of 275-284 days. Parturition was normal and without complications. Calves were removed from the dams within 1 hour after parturition. They did not suck the dams; instead they were hand-fed a known volume of colostrum using a nipple bottle. Calves received 2L of first colostrum within $2 \mathrm{~h}$ after birth and additional $2 \mathrm{~L}$ within $12 \mathrm{~h}$, by nipple feeding. In the postcolostral feeding period calves were provided with $2 \mathrm{~L}$ of whole milk twice a day.

\section{Collection of colostrum and isolation of colostral whey}

Two samples (No 1 and 2 in a volume of $200 \mathrm{~mL}$ ) of colostrum were collected from the first milking 2 - $3 \mathrm{~h}$ after calving into a sanitized milk bucket and were placed into plastic vials labelled with the cow identification number. Sample No 1 was analyzed within $1 \mathrm{~h}$ of collection with the digital Brix refractometer (Atago Co. Ltd., Tokyo, 
Japan). After the measurements, it was frozen and stored at $-20^{\circ} \mathrm{C}$ until used for the determination of colostral IgG concentration by RID (RID kit, The Binding Site group Ltd, Birmingham, UK). Sample No 2 was frozen and stored at $-20^{\circ} \mathrm{C}$ until used for the analysis of colostral whey proteins by electrophoresis. Frozen colostrum samples were thawed in a warm water bath $\left(37^{\circ} \mathrm{C}\right)$, brought up to room temperature $\left(20^{\circ} \mathrm{C}\right)$ and analyzed with RID within $4 \mathrm{~h}$ of thawing.

For isolation of colostral whey thawed colostrum was centrifuged (2000 rpm, $20 \mathrm{~min})$ and the fatty layer was carefully removed by vacuum aspiration. Casein was precipitated by adding seven drops (approximately $175 \mu \mathrm{L}$ ) of rennet to $10 \mathrm{ml}$ of centrifuged colostrum supernatant. After $30 \mathrm{~min}$ of incubation at $37^{\circ} \mathrm{C}$, samples were centrifuged for 15 minutes at $3000 \mathrm{x}$ g and colostral whey (supernatant) was aliquoted and stored at $-20^{\circ} \mathrm{C}$ until use.

\section{Calves blood samples collection and isolation of blood serum}

Whole blood was collected from 3-6 days old Holstein calves $(n=29)$ by jugular venipuncture into sterile, plastic, vacutainer tubes without anticoagulant. Samples $(6 \mathrm{~mL})$ were stored on ice and transported to the Faculty of Veterinary Medicine, University of Belgrade. Within 4-6 h of collection the serum was separated by centrifugation at $2000 \mathrm{x}$ for $15 \mathrm{~min}$.

\section{Brix refractometry}

The Brix refractometer was calibrated with distilled water before analysis of every sample. Then, colostrum or blood serum were homogenized by inverting 10 to 15 times, approximately $500 \mu \mathrm{L}$ of the sample was placed on the prism of the Brix refractometer, and \%Brix value was read. The digital Brix refractometer has a range from 0 to $85 \%$ Brix.

\section{Radial immunodiffusion (RID) assay}

The concentration of colostrum IgG was performed using a commercially available bovine IgG RID test plate (The Binding Site group Ltd, Birmingham, UK) according to the manufacturer. Colostrum samples were diluted 100-150 times with PBS (0.8\% $\mathrm{NaCl}, 10 \mathrm{mM}$ sodium-phosphate, $\mathrm{pH}$ 7.2-7.4) to ensure that sample ring diameters were within the range of the standards. Plates were incubated for 72 hours at 20 to $25^{\circ} \mathrm{C}$. The diameter of precipitation rings were measured using the ImageMaster TotalLab TL 120 software (GE Health Care Life Science, NJ, USA). IgG concentrations of colostrum samples were determined by comparing the diameter of the precipitation ring with a standard curve generated by assaying the internal standards of each kit. Concentrations of IgG standards were $2.5,1.25,0.62$ and $0.31 \mathrm{~g} / \mathrm{L}$. 


\section{Agarose gel serum protein electrophoresis (APE)}

APE of the colostral whey and serum proteins was performed according to the procedure of Johansson [28]. The eight samples (in volume of $3 \mu \mathrm{L}$ of each) were simultaneously separated in $0.1 \mathrm{~mm}$ tick, $1 \%$ agarose gel buffered with $46 \mathrm{mM}$ sodiumbarbital buffer, $\mathrm{pH}$ 8.6, poured on a glass plate. Electrophoresis was carried out in Multiphor II Electrophoresis System (GE Healthcare Bio-Sciences AB, Uppsala, Sweden) cooled with tap water. Sodium-barbital buffer (92 mM, pH 8.6) was used as the electrophoresis buffer. The proteins were separated for $50 \mathrm{~min}$ at constant current (6 $\mathrm{mA}$ per sample). After that the gel was dried at $65^{\circ} \mathrm{C}$, fixed and stained in $0.25 \%$ Coomassie blue R-250 in 10\% acetic acid/45\% methyl alcohol aqueous solution and destained in acetic acid/methyl alcohol aqueous solution. The relative content of $\gamma$ globulins (percentage) was quantified by densitometry using ImageMaster Total- Lab v1.11 software (Amersham Pharmacia Biotech, Uppsala Sweden). The concentration of $\gamma$ globulins was calculated based on total protein concentration determined by the biuret method as described by Doumas et al. [29].

\section{Statistical analysis}

The statistical significance of differences between concentration of colostral IgG estimated by RID and APE was determined by the two-tailed T test, using Microsoft Office Excel software. Differences with p-values of $<0.05$ were considered significant. The correlation between results of \% Brix and concentrations of colostral IgG and $\gamma$ globulin (RID and APE) and the correlation between \% Brix and concentrations of new-born serum $\gamma$ globulin (APE) were determined by linear correlation using OriginPro 8 software. Differences with p-values of $<0.05$ were considered significant.

\section{RESULTS}

Sixteen ( $\mathrm{n}=16)$ first milking composite colostrum samples were collected from Holstein-Friesian heifers. Their quality was assessed by Brix refractometry, and concentration of $\operatorname{IgG}$ and $\gamma$ globulin (containing mainly $\operatorname{IgG}$ ) were determined with RID and APE (Table 1, Figures 1 and 2). The mean \pm SD \% Brix score was $25.5 \pm 3.4 \%$. The concentration of total proteins in colostral whey was $134 \pm 30 \mathrm{~g} / \mathrm{L}$. In the agarose gel, proteins of colostrum whey were separated into fractions whose electrophoretic mobility corresponded to albumin, $\alpha, \beta$ and $\gamma$ globulins (Figure 1A). The relative concentration of the $\gamma$ globulin fraction (mostly IgG1) [33] was 75 44 $\%$. The absolute concentration $(\mathrm{g} / \mathrm{L})$ of $\gamma$ globulin was $100 \pm 24 \mathrm{~g} / \mathrm{L}$. When IgG was measured by RID (Figure 2) the concentration was $130 \pm 33 \mathrm{~g} / \mathrm{L}$.

The correlation between results obtained with Brix refractometer and concentrations of total colostral whey proteins, $\gamma$ globulins (i.e. IgG) measured with APE and IgG measured with RID was determined by linear correlation analysis (Figure 3). Correlation between Brix values and the concentrations of $\operatorname{IgG}$ determined with both methods 
and also the correlation between Brix values and concentration of total colostral whey proteins was positive and statistically highly significant $(\mathrm{P}<0.001$ and $\mathrm{P}<0.01)$. We also compared the concentration of colostral IgG obtained by APE (colostral whey $\gamma$ globulins) and RID (whole colostrum $\operatorname{IgG}$ ) and found that there was a statistically significant positive correlation $(\mathrm{P}<0.001)$ between these two techniques (Figure 4). However, concentrations of $\gamma$ globulins obtained by APE were significantly lower than concentrations of IgG obtained by RID (21 $16 \%)$. The correlation between colostral whey protein and colostral IgG was positive and statistically significant, independently of the method used for the determination of $\operatorname{IgG}$ concentration (Figure 5).

Table 1. Assessing the colostrum quality by Brix measurement and by determination of the colostral $\gamma$ globulin with agarose gel serum protein electrophoresis (APE) and colostral IgG with radial immunodiffusion (RID).

\begin{tabular}{|c|c|c|c|c|c|}
\hline \multirow{2}{*}{$\begin{array}{c}\text { Samples } \\
\mathrm{n}=16\end{array}$} & \multirow{2}{*}{$\begin{array}{c}\text { Brix }^{1} \\
(\%)\end{array}$} & \multirow{2}{*}{$\begin{array}{c}\text { Total col. whey proteins } \\
(\mathrm{g} / \mathrm{l})\end{array}$} & \multicolumn{2}{|c|}{$\gamma$ globulin by APE } & \multirow{2}{*}{$\begin{array}{c}\text { IgG by RID } \\
(\mathrm{g} / \mathrm{l})\end{array}$} \\
\hline & & & $(\%)^{3}$ & $(\mathrm{~g} / \mathrm{l})^{4}$ & \\
\hline 1 & 21,5 & 106 & 74 & 78 & 70 \\
\hline 2 & 20,7 & 91 & 77 & 70 & 97 \\
\hline 3 & 26,2 & 147 & 78 & 115 & 129 \\
\hline 4 & 29,0 & 168 & 77 & 129 & 159 \\
\hline 5 & 28,2 & 171 & 73 & 124 & 165 \\
\hline 6 & 27,3 & 146 & 76 & 111 & 140 \\
\hline 7 & 18,0 & 84 & 74 & 62 & 65 \\
\hline 8 & 26,5 & 136 & 72 & 98 & 155 \\
\hline 9 & 28,1 & 137 & 74 & 102 & 142 \\
\hline 10 & 30,8 & 163 & 71 & 115 & 143 \\
\hline 11 & 24,6 & 114 & 76 & 87 & 85 \\
\hline 12 & 28,4 & 181 & 76 & 138 & 165 \\
\hline 13 & 26,2 & 116 & 79 & 92 & 160 \\
\hline 14 & 25,8 & 114 & 71 & 81 & 135 \\
\hline 15 & 25,0 & 104 & 67 & 70 & 123 \\
\hline 16 & 22,4 & 161 & 84 & 135 & 154 \\
\hline mean & 25,5 & 134 & 75 & 100 & 130 \\
\hline SD & 3,4 & 30 & 4 & 24 & 33 \\
\hline mediana & 26,2 & 137 & 75 & 100 & 141 \\
\hline $\min$ & 18,0 & 84 & 67 & 62 & 65 \\
\hline $\max$ & 30,8 & 181 & 84 & 138 & 165 \\
\hline CV $(\%)$ & 13 & 23 & 5 & 24 & 26 \\
\hline
\end{tabular}

${ }^{1}$ Colostral Brix readings; ${ }^{2}$ Total proteins in colostral whey determined by Biuret reaction; ${ }^{3}$ Relative content of $\gamma$ globulins (\%) determined by APE; ${ }^{4}$ Concentration of colostral $\gamma$ globulins determined by APE and densitometry.; ${ }^{5}$ Concentration of colostral $\mathrm{IgG}$ determined by RID 

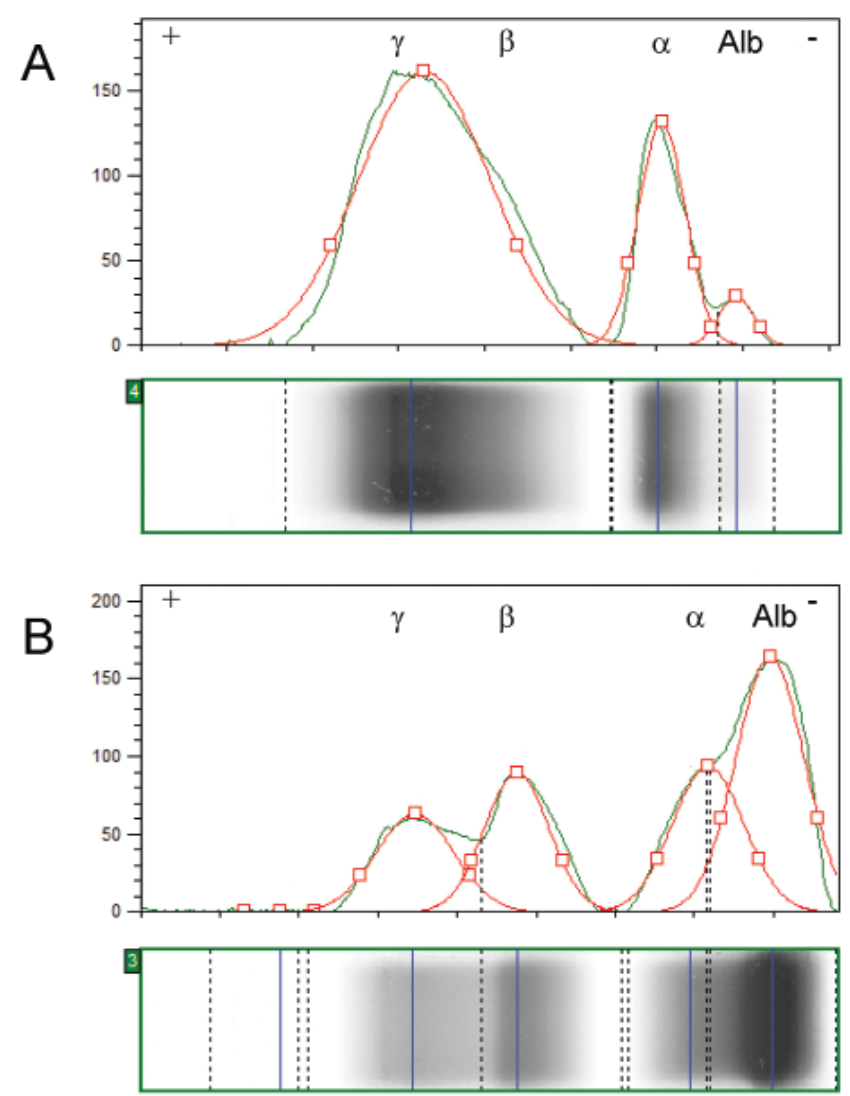

Figure 1. Agarose gel protein electrophoretic (APE) pattern in heifer's colostral whey (A) and new-born calf serum (B). $\alpha-\alpha$ globulin, $\beta-\beta$ globulin, $\gamma-\gamma$ globulin; Dark line: Densitometry recorded color intensity; Red line: Deconvolution of the densitometric profile.

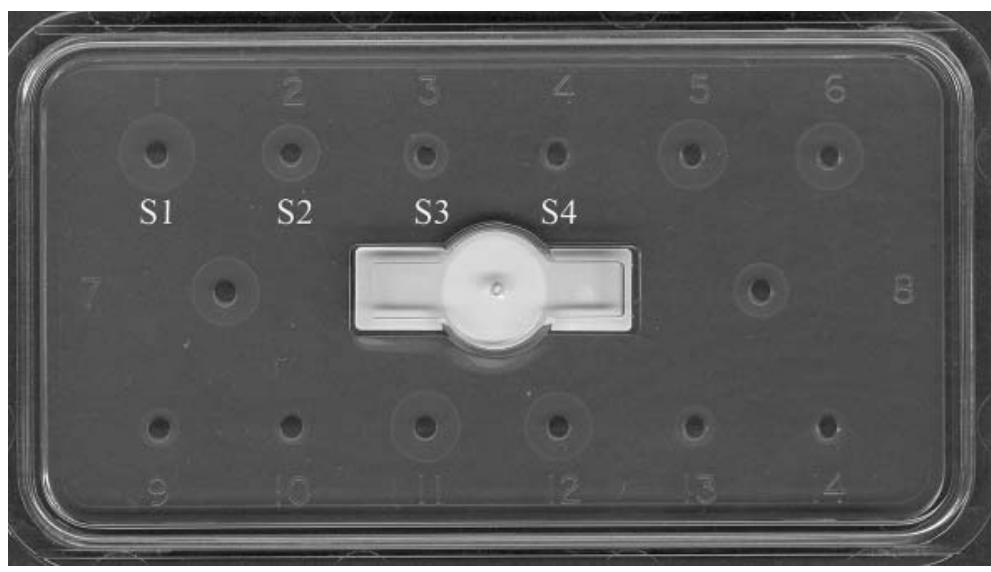

Figure 2. Determining the concentration of colostral IgG with radial immunodiffusion (RID) assay. Wells 1-4, S1-S4: Standard IgG samples containing 2.5, 1.25, 0.62, and $0.31 \mathrm{~g} / \mathrm{L} \mathrm{IgG}$ respectively. Wells 5-14: Diluted colostrum samples. 


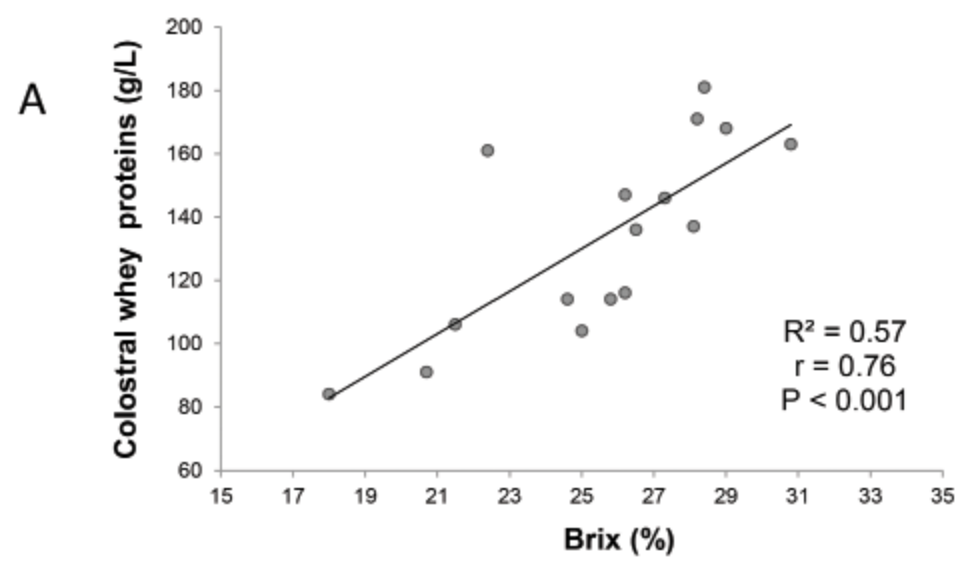

B
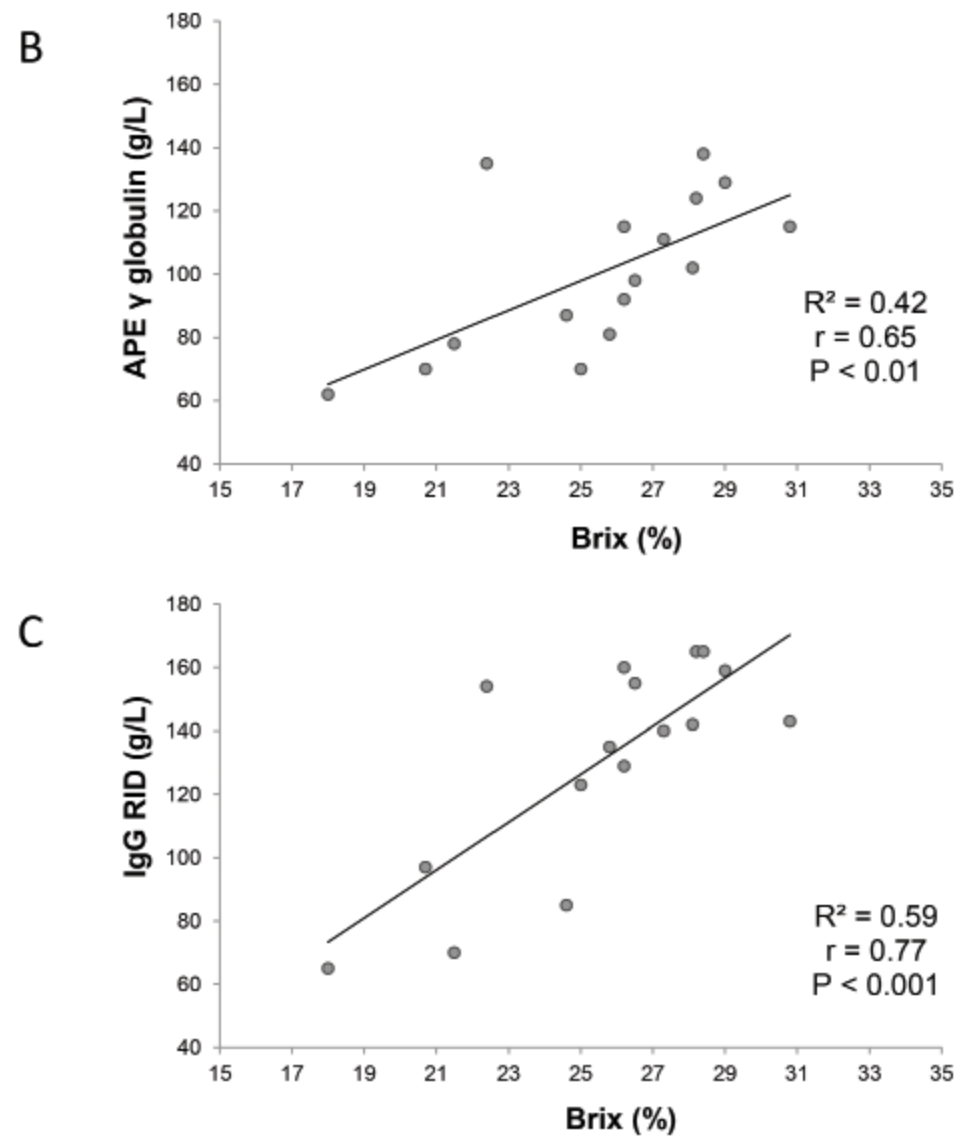

Figure 3. Correlation between Brix scores (\%) and total colostral proteins (A), APE determined concentration of $\gamma$ globulins (B) and RID determined concentration of colostral $\operatorname{IgG}(\mathbf{C}) .(\bullet)$ - Experimental data; $(-)$ - Linear regression analysis. 


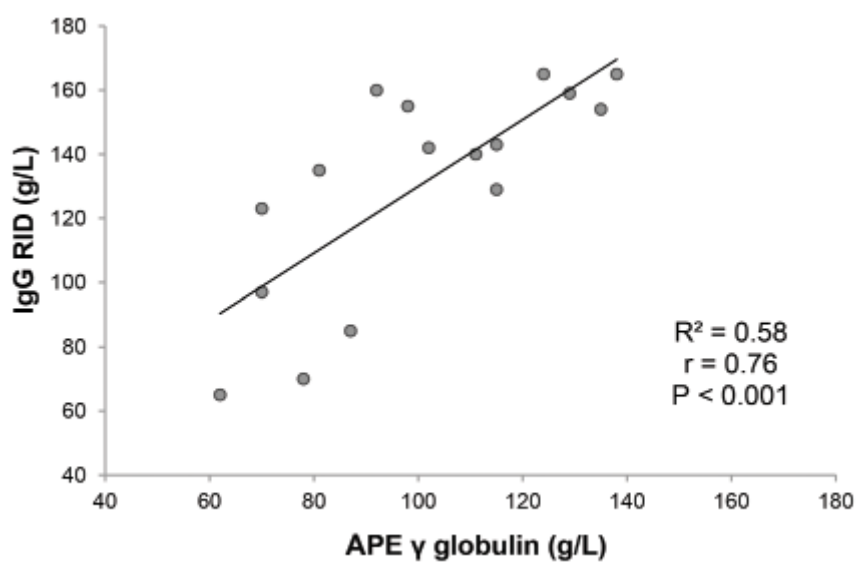

Figure 4. Correlation between APE determined concentration of $\gamma$ globulins and RID determined concentration of colostral IgG. $(\bullet)$ - Experimental data; $(-)$ - Linear regression analysis.

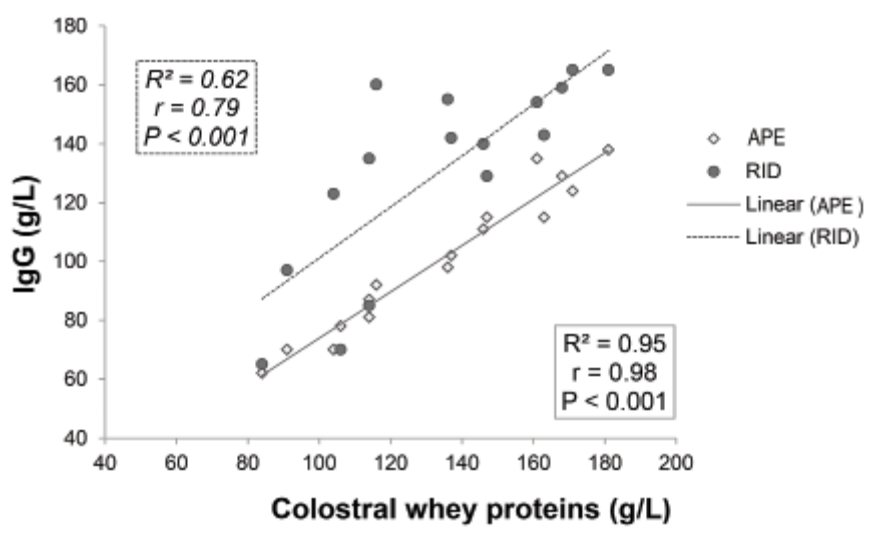

Figure 5. Correlation between APE determined concentration of $\gamma$ globulins (IgG) and RID determined concentration of colostral $\operatorname{IgG}()$ and concentration of total colostral proteins. $(\bullet)$ - Experimental data; $(-)$ - Linear regression analysis for APE; (......) - Linear regression analysis for RID. APE: $\mathrm{R}^{2}, \mathrm{r}$, and $\mathrm{P}$ given in regular letter. RID: $\mathrm{R}^{2}, \mathrm{r}$, and $\mathrm{P}$ given in italic.

Further on we evaluated FPT by analyzing the 3-6 days old calves' blood sera with Brix refractometry, the concentration of total blood serum proteins and the concentration of $\gamma$ globulins $(\mathrm{IgG})$ determined by APE (Table 2, Figure 1B). The mean total serum protein concentration was $57.75 \pm 11.8 \mathrm{~g} / \mathrm{L}, \gamma$ globulins concentration was $14.4 \pm 7.8$ $\mathrm{g} / \mathrm{L}$ and the Brix score was $8.6 \pm 1.0 \% .10$ samples had $\gamma$ globulins concentrations lower than $10 \mathrm{~g} / \mathrm{L}$, consistent with inadequate passive transfer. The percentage of calves with FPT $(\operatorname{IgG}<10 \mathrm{~g} / \mathrm{L})$ was $34.5 \%$ (10/29 calves). Brix score significantly correlated with the concentration of blood serum $\gamma$ globulins in all examined calves (Figure 6). Thus, a value of \% Brix score lower than 8.6 (mean+2SD), which reflects a concentration of serum $\gamma$ globulin of $<10 \mathrm{~g} / \mathrm{L}$, most accurately predicted FPT. Unlike $\gamma$ globulins, total serum proteins positively correlated with Brix scores only in sera 
having more than $10 \mathrm{~g} / \mathrm{L} \gamma$ globulins. In accordance with this finding was the result showing that the concentration of total serum proteins positively correlated with the level of $\gamma$ globulins only if their concentration exceeded $10 \mathrm{~g} / \mathrm{L}$ (Figure 7).
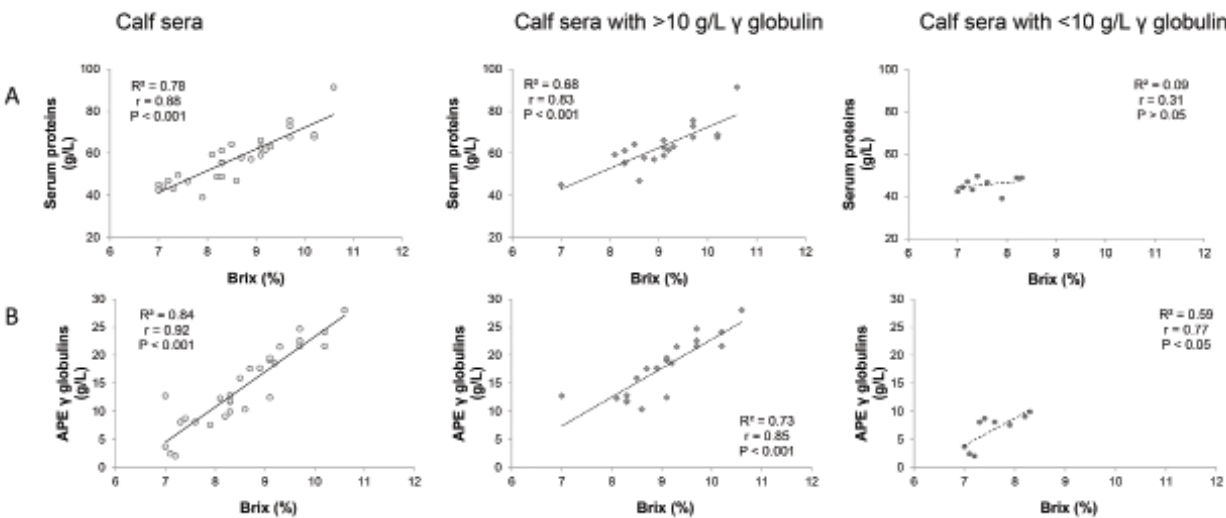

Figure 6. Correlation between Brix scores (\%) and total new-born serum proteins (A), APE determined concentration $\gamma$ globulins $(\mathbf{B}) .(\mathrm{o}, \bullet, \bullet$,$) - Experimental data for total sera, sera$ having less $10 \mathrm{~g} / \mathrm{L}$ and sera more than $10 \mathrm{~g} / \mathrm{L}$ of $\gamma$ globulins; $(-)$ - Linear regression analysis.

Table 2. Quality of new-born calves' sera assessed by Brix refractometer and by agarose gel serum protein electrophoresis (APE)

\begin{tabular}{|c|c|c|c|c|}
\hline & \multirow{2}{*}{$\begin{array}{l}\text { Brix }^{1} \\
(\%)\end{array}$} & \multirow{2}{*}{$\begin{array}{l}\text { Total serum roteins }{ }^{2} \\
(\mathrm{~g} / \mathrm{l})\end{array}$} & \multicolumn{2}{|c|}{$\gamma$ globulin by APE } \\
\hline & & & $(\%)^{3}$ & $(g / 1)^{4}$ \\
\hline \multicolumn{5}{|c|}{ All sera $(n=29)$} \\
\hline mean $\pm \mathrm{SD}$ & $8.6 \pm 1.0$ & $57.5 \pm 11.8$ & $23.3 \pm 8.3$ & $14.4 \pm 7.8$ \\
\hline median & 8.5 & 57.9 & 23.2 & 12.8 \\
\hline$(\min -\max )$ & $(7.0-10.6)$ & $(39.0-91.4)$ & $(4.3-35.7)$ & $(2.0-28.0)$ \\
\hline CV $(\%)$ & 11.9 & 20.6 & 34.9 & 48.4 \\
\hline \multicolumn{5}{|c|}{$>10 \mathrm{~g} / \mathrm{L} \gamma$ globulin $(\mathrm{n}=19)$} \\
\hline mean $\pm \mathrm{SD}$ & $9.0 \pm 0.7$ & $63.9 \pm 9.4$ & $28.0 \pm 5.1$ & $18.1 \pm 5.1$ \\
\hline median & 9.1 & 62.7 & 30.4 & 18.6 \\
\hline$(\min -\max )$ & $(8.1-10.6)$ & $(46.9-91.4)$ & $(19.4-35.7)$ & $(10.4-28.0)$ \\
\hline CV $(\%)$ & 9.5 & 14.8 & 18.4 & 28.4 \\
\hline \multicolumn{5}{|c|}{$<10 \mathrm{~g} / \mathrm{L} \gamma$ globulin $(\mathrm{n}=10)$} \\
\hline mean $\pm \mathrm{SD}$ & $7.6 \pm 0.5$ & $45.5 \pm 3.5$ & $14.5 \pm 6.4$ & $6.6 \pm 3.0$ \\
\hline median & 7.4 & 46.6 & 17.6 & 8.1 \\
\hline$(\min -\max )$ & $(7.0-8.3)$ & $(39.0-49.6)$ & $(4.3-20.3)$ & $(2.0-9.9)$ \\
\hline CV $(\%)$ & 6.3 & 7.8 & 44.1 & 45.7 \\
\hline
\end{tabular}

${ }^{1}$ Serum Brix readings; ${ }^{2}$ Total proteins in serum by Biuret reaction; ${ }^{3}$ Relative content of $\gamma$ globulins $(\%)$ determined by APE; ${ }^{4}$ Concentration of serum $\gamma$ globulin determined by APE and densitometry. 


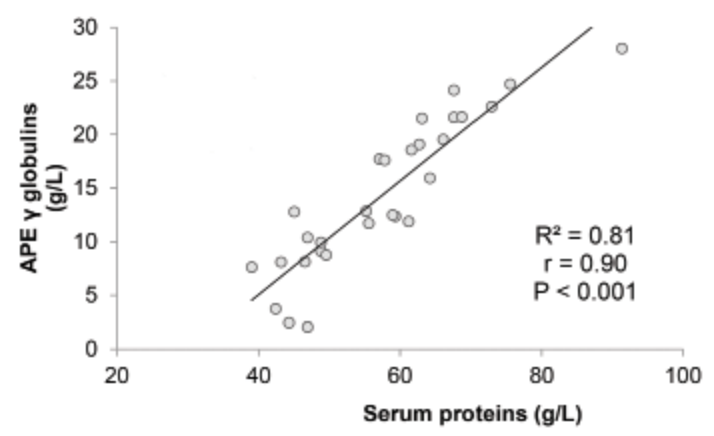

\section{Calf sera}

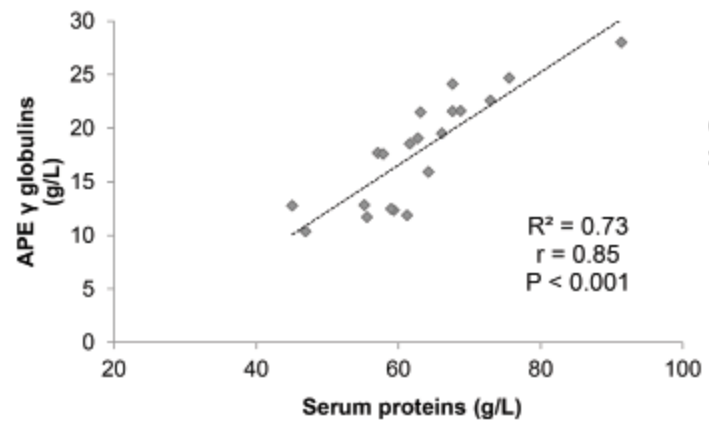

\section{Calf sera}

$>10 \mathrm{~g} / \mathrm{L}$ y globulin

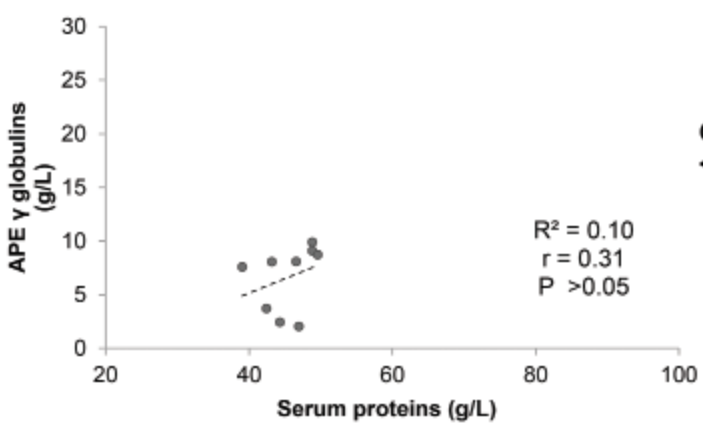

Figure 7. Correlation between the APE determined concentration of $\gamma$ globulins and the concentration of total new-born serum proteins. $(\mathrm{O}, \bullet, \bullet$,$) - Experimental data for total sera,$ sera having less $10 \mathrm{~g} / \mathrm{L}$ and sera more than $10 \mathrm{~g} / \mathrm{L}$ of $\gamma$ globulins; $(-)$ - Linear regression analysis.

\section{DISCUSSION}

The concentration of $\operatorname{IgG}$ in the colostrum has traditionally been considered the most important component for evaluating colostrum quality as high-quality colostrum is considered the one which has more than $50 \mathrm{~g} / \mathrm{L} \mathrm{IgG} \mathrm{[10].} \mathrm{The} \mathrm{current} \mathrm{recommendation}$ is to assess the quality of collected colostrum before it is fed to calves [1], but this is not applied on our farms. On the farms owned by PKB Corporation (Belgrade, Serbia) colostrum quality is estimated by colostrometry and visual inspection. However, several studies $[20,31,32]$ reported a low correlation between the concentration of colostral 
IgG measured by RID and colostral specific gravity. Refractometry with the Brix refractometer has been proposed as a way to estimate $\operatorname{IgG}$ concentration in bovine colostrum [1]. Both the optical and digital Brix refractometers showed considerable potential in determining colostrum quality [1]. The same authors reported that Brix refractometry gave accurate results independently whether colostrum samples were fresh or frozen.

Brix refractometers are widely used in dairy farms in developed countries. On our dairy farms it is not used at all, even though its price is not an obstacle. In the current study we undoubtedly showed the importance of applying refractometry thus recommending it for testing the colostrum quality. In accordance with the results of Bartens et al. [33] our results also showed that the Brix refractometer has provided a rapid and accurate tool for the measurement of colostral IgG and determination of colostrum quality. In our study we showed that Brix values were highly correlated with colostral IgG analyzed by RID. This finding is similar to the results of other research groups $[1,15,34,35]$, who also found a moderate to high correlation between $\%$ Brix and IgG measured by RID. Besides we found that there was a significant, but somewhat lower, correlation between the results obtained with the Brix refractometer and the concentration of colostral whey IgG measured with APE. We have not expected that the two methods provide identical results because in the fraction of $\gamma$ globulins, beside IgG representing the predominant class of immunoglobulins, there are small amounts of $\operatorname{IgM}$ and $\operatorname{IgA}$ in colostral whey and calf serum after colostrum ingestion [36]. However, the recorded lower concentration of colostral whey $\mathrm{IgG}$ is not unexpected. It is known that bovine IgG might form complexes with lipids [37] and its removal by centrifugation of colostrum can be one of the reasons for a lower concentration of $\mathrm{IgG}$ in colostral whey. Besides, any purification process (such as removal of colostrum lipids by centrifugation followed by casein precipitation) results in a decreased in yield of purified molecules. Independently of the lower yield of colostral whey $\gamma$ globulins, their concentration determined by APE significantly correlated with the concentration of colostral IgG determined by RID. This result pointed that APE can be used as an accurate method for laboratory determination of $\mathrm{IgG}$ in bovine colostrum and it can be used for the assessment of colostrum quality when RID is not available.

Data on APE analysis of bovine colostral whey proteins are rare. We found that a relative concentration of colostral whey $\gamma$ globulins $(\mathrm{IgG})$ was $75 \pm 4 \%$. Lopez et al. [38], using cellulose acetate electrophoresis, reported a relative concentration of colostral whey $\gamma$ globulin of $62.4 \%$ within 12 hours of delivery. Besides, we found that the significant correlation between colostral whey IgG and total colostral whey proteins can be also confirmed by APE. According to our knowledge APE is not used by other research groups for determining this correlation. However, Chen et al. [39] and Quiles et al. [40] applying APE, confirmed the significant correlation coefficient between colostral $\gamma$ globulin and total protein in goats during the first 5 days after parturition. Such a high correlation gives us the possibility to use the biuret method for rapid screening of colostrum quality in laboratory work. This correlation is due to 
the fact that the $\operatorname{IgG}$ is the predominant immunoglobulin and predominant protein in the colostrum [14].

Our previous studies estimated FPT and IgG concentration in calves serum using RID as the gold standard. Knowing that the Brix refractometer can be used to measure IgG concentrations in the calf serum [41] we have investigated further options for its application on our farms. Its advantages were previously described by Wallace et al. [42] who reported that the results of refractometry from centrifuge- and noncentrifugeharvested sources of serum were highly correlated so producers can conduct this test on-farm without the need of a centrifuge. Similar to results of Deelen et al. [41], our results showed that \% Brix highly correlated with the concentration of serum IgG, when all calves where considered, independently of the serum $\operatorname{IgG}$ concentration. This result undoubtedly showed that Brix refractometry can be used for assessing FPT. Also, similar to Deelen et al. [41] we found a correlation between \% Brix and total serum proteins when all sera were included in the calculation. However, when we analyzed sera of calves with FPT $(<10 \mathrm{~g} / \mathrm{L} \mathrm{IgG)}$ we did not find a significant correlation between $\%$ Brix and the concentration of total serum proteins. Besides, we did not find correlations between total serum proteins and serum IgG. It is known that different proteins do not have the same refractive indexes. We think that in the sera of calves with FPT, decrease of total serum proteins concentration and the differences in relative concentrations (percentages) in the major protein fractions (data not shown) probably results in an absence of correlation between the analyzed parameters.

\section{CONCLUSION}

The result of this study have confirmed that Brix refractometer scores were highly correlated with the concentration of both measured colostral IgG and new-born calves serum IgG which means that digital Brix refractometry allows producers to use this technique to estimate colostral and calf serum $\operatorname{IgG}$, thereby monitoring both colostrum quality and success of passive transfer.

\section{Acknowledgement}

This work was supported by III46002, TR 31050 and III46010 grants from the Ministry of Education, Science and Technological Development of Republic of Serbia.

RID kit (The Binding Site group Ltd, Birmingham, UK) was donated by Patent Co company, Mišićevo, Subotica, Serbia.

\section{Authors' contributions}

SM performed all experiment, analysis data and wrote the manuscript. FN designed and oversaw th research, analysed data and wrote the manuscript. IV helped in extablishing analytical methods, analysed data and assisted with preparation of the manuscript. 
KM and SO performed experiment and analysed data. GD, ĐR nad VO critically read the manuscript and assisted with preparation of the manuscript. All authors read and approved the final manuscript.

\section{Declaration of conflicting interests}

The author(s) declared no potential conflicts of interest with respect to the research, authorship, and/or publication of this article.

\section{REFERENCES}

1. Bielmann V, Gillan J, Perkins NR, Skidmore AL, Godden S, Leslie KE: An evaluation of Brix refractometry instruments for measurement of colostrum quality in dairy cattle. J Dairy Sci 2010, 93:3713-3721.

2. Weaver DM, Tyler JW, VanMetre DC, Hostetler DE, Barrington GM: Passive transfer of colostral immunoglobulins in calves. J Vet Intern Med 2000, 14:569-577.

3. Chigerwe M, Tyler JW, Nagy DW, Middleton JR: Frequency of detectable serum IgG concentrations in precolostral calves. Am J Vet Res 2008, 69:791-795.

4. Quigley J: Passive Immunity in Newborn Calves. Advances in Dairy Technology 2002, 14:273-292.

5. Reber AJ, Donovan DC, Gabbard J, Galland K, Aceves-Avila M, Holbert KA, Marshall L, Hurley DJ: Transfer of maternal colostral leukocytes promotes development of the neonatal immune system I. Effects on monocyte lineage cells. Vet Immunol Immunop 2008, 123:186-196.

6. Reber AJ, Donovan DC, Gabbard J, Galland K, Aceves-Avila M, Holbert KA, Marshall L, Hurley DJ: Transfer of maternal colostral leukocytes promotes development of the neonatal immune system Part II. Effects on neonatal lymphocytes. Vet Immunol Immunop 2008, 123:305-313.

7. Donovan GA, Dohoo IR, Montgomery DM, Bennett FL: Associations between passive immunity and morbidity and mortality in dairy heifers in Florida, USA. Prev Vet Med 1998, 34:31-46.

8. Tyler JW, Hancock DD, Thorne JG, Gay CC, Gay JM: Partitioning the mortality risk associated with inadequate passive transfer of colostral immunoglobulins in dairy calves. J Vet Intern Med 1999, 13:335-337.

9. McGuirk SM: Reducing dairy calf mortality. In: Proceedings of the 40th Annual Conference of the American Association of Bovine Practitioners, Vancouver, BC, Canada 2007, 40:126-131.

10. Lorenz I, Mee JF, Earley B, More SJ: Calf health from birth to weaning. I. General aspects of disease prevention. Irish Vet J 2011, 64:10.

11. Hogan I, Doherty M, Fagan J, Kennedy E, Conneely M, Brady P, Ryan C, Lorenz I: Comparison of rapid laboratory tests for failure of passive transfer in the bovine. Irish Vet J 2015, 68:18.

12. Godden S: Colostrum management for dairy calves. Vet Clin N Am-Food A 2008, 24:1939. 
13. McGuirk SM: Disease management of dairy calves and heifers, Vet Clin N Am- Food A 2008, 24:139-153.

14. Gapper LW, Copestake DE, Otter DE, Indyk HE: Analysis of bovine immunoglobulin G in milk, colostrum and dietary supplements: A review. Anal Bioanal Chem 2007, 389:93109.

15. Quigley JD, Lago A, Chapman C, Erickson P, Polo J: Evaluation of the Brix refractometer to estimate immunoglobulin $G$ concentration in bovine colostrum. J Dairy Sci 2013, 96:1148-1155.

16. Fleenor WA, Stott GH: Single radial immunodiffusion analysis for quantitation of colostral immunoglobulin concentration. J Dairy Sci 1981, 64:740-747.

17. Lee SH, Jaekal J, Bae CS, Chung BH, Yun SC, Gwak MJ, Noh GJ, Lee DH: Enzyme Linked Immunosorbent Assay, Single Radial Immunodiffusion, and Indirect Methods for the Detection of Failure of Transfer of Passive Immunity in Dairy Calves. J Vet Intern Med 2008, 22:212-218.

18. Cerón JJ, Caldin M, Martinez-Subiela S: Electrophoresis and acute phase protein measurement. In: Schalm's Veterinary Hematology. 6th ed. Ames, Iowa: Blackwell Publishing; 2010, 1157-1161.

19. Fleenor WA, Stott GH: Hydrometer test for estimation of immunoglobulin concentration in bovine colostrum. J Dairy Sci 1980, 63:973-977.

20. Morin DE, Constable PD, Maunsell FP, McCoy GC: Factors associated with colostral specific gravity in dairy cows. J Dairy Sci 2001, 84:937-943.

21. Mechor GD, Gröhn YT, Van Saun RJ: Effect of temperature on colostrometer readings for estimation of immunoglobulin concentration in bovine colostrum. J Dairy Sci 1991, 74:3940-3943.

22. Mechor GD, Gröhn YT, McDowell LR, Van Saun RJ: Specific gravity of bovine colostrum immunoglobulins as affected by temperature and colostrum components. J Dairy Sci 1992, 75:3131-3135.

23. Calloway CD, Tyler JW, Tessman RK, Hostetler D, Holle J: Comparison of refractometers and test endpoints in the measurement of serum protein concentration to assess passive transfer status in calves. JAVMA-J Am Vet Med A 2002, 221:1605-1608.

24. Moore DA, Taylor J, Hartman ML, Sischo WM: Quality assessments of waste milk at a calf ranch. J Dairy Sci 2009, 92:3503-3509.

25. Morrill KM, Robertson KE, Spring MM, Robinson AL, Tyler HD: Validating a refractometer to evaluate immunoglobulin $\mathrm{G}$ concentration in Jersey colostrum and the effect of multiple freeze-thaw cycles on evaluating colostrum quality. J Dairy Sci 2015, 98:595-601.

26. Chavatte P, Clément F, Cash R, Grongnet JF: Field determination of colostrum quality by using a novel, practical method. In: Proceedings of the Annual Convention of the AAEP 1998, 44:206-209.

27. Morrill KM, Conrad E, Polo J, Lago A, Campbell J, Quigley J, Tyler H: Estimate of colostral immunoglobulin $\mathrm{G}$ concentration using refractometry without or with caprylic acid fractionation. J Dairy Sci 2012, 95:3987-3996.

28. Johansson BG: Agarose gel electrophoresis. Scand J Clin Lab Inv 1972, 124:7-19.

29. Doumas BT, Bayse DD, Carter RJ, Peters T, Schaffer R: A candidate reference method for determination of total protein in serum. I. Development and validation. Clin Chem1981, 27:1642-1650. 
30. Kickofen B, Hammer DK, Scheel D: Isolation and characterization of gamma G type immunoglobulins from bovine serum and colostrum. Hoppe-seyler's Z Physiol Chem. 1968, 349-351.

31. Pritchett LC, Gay CC, Hancock DD, Besser TE: Evaluation of the Hydrometer for Testing Immunoglobulin G1 Concentrations in Holstein Colostrum1. J Dairy Sci 1994, 77:17611767.

32. Quigley JD, Martin KR, Dowlen HH, Wallis LB, Lamar K: Immunoglobulin concentration, specific gravity, and nitrogen fractions of colostrum from Jersey cattle. J Dairy Sci 1994, 77:264-269.

33. Bartens MC, Drillich M, Rychli K, Iwersen M, Arnholdt T, Meyer L, Klein-Jöbstl D: Assessment of different methods to estimate bovine colostrum quality on farm. New Zeal Vet J 2016, 64:263-267.

34. Elsohaby I, McClure JT, Cameron M, Heider LC, Keefe GP: Rapid assessment of bovine colostrum quality: How reliable are transmission infrared spectroscopy, and digital and optical refractometers?. J Dairy Sci 2017, 100:1427-1435.

35. Chigerwe M, Tyler JW, Middleton JR, Spain JN, Dill JS, Steevens BJ: Comparison of four methods to assess colostral IgG concentration in dairy cows. JAVMA-J Am Vet Med A 2008, 233:761-766.

36. Mohendra JGS Merriman: Serum immunoglobulins in newborn calves before and after colostrum feeding. Can J Comp Med 1971, 35: 269-273.

37. Vitić J: Sastav serumskih lipoproteida nekih sisara i promene lipoproteida pod uslovima eksperimentalno izazvanih dislipidemija. Ph.D. Disertation, University of Belgrade, Serbia, 1983.

38. Lopez JW, Allen SD, Mitchell J, Quinn M: Rotavirus and Cryptosporidium shedding in dairy calf feces and its relationship to colostrum immune transfer. J Dairy Sci 1988, 71: 1288-1294.

39. Chen JC, Chang JC, Peh HC, Chen SY: Serum protein levels and neonatal growth rate of Nubian goat kids in Taiwan area. Small Ruminant Res 1999, 32:153-160.

40. Quiles AJ, Gonzalo C, Fuentes F, Hevia M, Sanchez JM: Protein composition and variation of caprine colostrum (Murciano-Granadina breed) by means of polyacrylamide-SDS gel electrophoresis. Anim Sci 1991, 52:311-316.

41. Deelen SM, Ollivett TL, Haines DM, Leslie KE: Evaluation of a Brix refractometer to estimate serum immunoglobulin G concentration in neonatal dairy calves. J Dairy Sci 2014, 97:3838-3844.

42. Wallace MM, Jarvie BD, Perkins NR, Leslie KE: A comparison of serum harvesting methods and type of refractometer for determining total solids to estimate failure of passive transfer in calves. Can Vet J 2006, 47:573-575. 


\title{
BRIX REFRAKTOMETRIJA KOLOSTRUMA PRVOTELKI MLEČNIH KRAVA I KRVNOG SERUMA NOVOROĐENE TELADI U PROCENI NEUSPEŠNOG PASIVNOG TRANSFERA
}

\author{
STOJIĆ Milica, FRATRIĆ Natalija, KOVAČIĆ Marijana, ILIĆ Vesna, \\ GVOZDIĆ Dragan, SAVIĆ Olivera, ĐOKOVIĆ Radojica, VALČIĆ Olivera
}

Neuspešan pasivni transfer (FPT) imunoglobulina $(\operatorname{Ig} G)$ u vezi je sa povećanim morbiditetom i mortalitetom kod teladi. U ovoj studiji vršili smo procenu upotrebe Brix refraktometra za utvrđivanje FPT. Digitalnim Brix refraktometrom analizirano je ukupno 16 uzoraka kolostruma iz prve muže (2-3h posle teljenja) od junica holštajn frizijske rase i 29 uzoraka krvnog seruma teladi iste rase, starosti 3-6 dana. Ukupni proteini određeni su biuretskom metodom. Kolostralni IgG su određivani radijalnom imunodifuzijom (RID), a $\gamma$ globulini (u čijem sastavu su pregomintno IgG) kolostralnog i krvnog seruma elektroforezom u gelu agaroze (APE) i denzitometrijom. Dobijene vrednosti za \% Brix-a u kolostrumu iznosile su 25,5 $\pm 3,4 \%$. Koncentracije IgG u kolostrumu i $\gamma$ globulina u kolostralnom serumu bile su $130 \pm 33 \mathrm{~g} / \mathrm{l}$ i $100 \pm 24 \mathrm{~g} / \mathrm{l}$ pojedinačno. Koncentracija ukupnih proteina u kolostralnom serumu iznosila je 134 $\pm 30 \mathrm{~g} / 1$. Korelacija izmedu vrednosti Brix-a i koncentracije IgG određenih RID i $\gamma$ globulina određenih APE metodom bila je pozitivna i visoko statistički značajna ( $\mathrm{P}<0,001$ i $\mathrm{P}<0,01)$. Koncentracija serumskih proteina novorođene teladi bila je 57,75 $\pm 11,8 \mathrm{~g} / 1$, koncentracija $\gamma$ globulina $14,4 \pm 7,8 \mathrm{~g} / \mathrm{l}$ a vrednosti

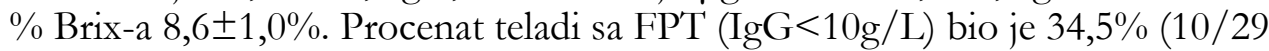
teladi). Vrednosti dobijene Brix-om značajno koreliraju sa koncentracijom $\gamma$ globulina ( $\operatorname{IgG}$ ) krvnog seruma kod svih ispitivanih teladi. Rezultati ove studije pokazuju da upotreba digitalnog Brix refraktometra omogućava proizvođačima upotrebu ove tehnike za procenu IgG kolostruma i seruma teladi, što znači da se može istovremeno koristiti za praćenje kvaliteta kolostruma kao i uspešnog pasivnog transfera. 